\title{
Faktor-faktor yang berhubungan dengan Usia Menarche Siswi SMP PGRI Pekanbaru
}

\author{
Factors Associated with Age of Menarche Junior High School Student PGRI \\ Pekanbaru
}

\section{Novita Lusiana}

\section{Program Studi D III Kebidanan STIKes Hang Tuah Pekanbaru}

\begin{abstract}
Abstrak
Beberapa penelitian terakhir menunjukkan kecendrungan semakin cepatnya remaja putri mengalami menarche yang berarti semakin cepat memasuki masa reproduksi. Tujuan penelitian ini untuk mengetahui faktor-faktor yang berhubungan dengan usia menarche siswi, antara lain usia menarche ibu, status gizi dan status sosial ekonomi. Penelitian ini menggunakan metode analitik kuantitatif, dengan desain cross sectional yang dilaksanakan pada bulan Maret - April 2012 di SMP PGRI Pekanbaru. Tehnik pengambilan sampel dilakukan dengan acak sederhana simple random sampling. Subjek penelitian ini adalah siswi kelas VII dan VIII SMP PGRI Pekanbaru berjumlah 62 orang. Alat ukur yang digunakan adalah kuesioner. Analisis data yang digunakan dalam bivariat dengan uji Chi-Square. Hasil penelitian menunjukkan sebagian besar siswi mengalami menarche pada usia normal sebanyak 43 orang siswi $(69,4 \%)$, ibu yang mengalami menarche pada usia normal sebanyak $49 \mathrm{ibu}$ siswi $(79,0 \%)$, dengan signifikan sebesar 0,015 (p value $<0,05$ ) dengan OR= 5,52. Status gizi normal sebanyak 48 siswi $(77,4 \%$ ), dengan signifikan sebesar 0,022 (p value $<0,05$ ) dengan OR 4,48 dan status sosial ekonomi tinggi sebanyak 40 siswi $(64,5 \%$ ), dengan signfikan sebesar 0,004 (p value $<0,05$ ) dengan $\mathrm{OR}=5,65$. Diharapkan adanya kerjasama antara pihak sekolah dengan petugas Pelayanan Kesehatan Peduli Remaja (PKPR) untuk memberikan penyuluhan tentang kesehatan reproduksi remaja usia 12-18 tahun terutama tentang menarche.
\end{abstract}

Kata Kunci : Usia menarche ibu, status gizi, sosial ekonomi, Usia menarche, siswi SMP

\begin{abstract}
Some recent research suggests the likelihood of an accelerated teenage girls experience menarche, which means the faster entering the reproductive period. The purpose of this study to determine the factors associated with age of menarche girls, including maternal age of menarche, nutritional status and socioeconomic status. This study uses quantitative analytical methods, with cross sectional design, are carried out from March-April 2012 in Junior High School PGRI Pekanbaru. Sampling technique is done by simple random sampling simple random The subject of this study was grade VII and VIII SMP PGRI Pekanbaru numbered 62 people. Measuring instrument used was quesionnaire. Data for bivariate analysis with ChiSquare test. The results obtained most of the girls experienced menarche at normal age of female students by 43 people (69.4\%), women who experienced menarche at normal age of mothers was 49 students (79.0\%), with significantly by 0.015 (p value $<0$, 05) with $O R=5,52$. Normal nutritional status of as many as 48 students (77.4\%), with significantly by 0.022 ( $p$ value $<0.05$ ) with $O R=4,48$ and high socioeconomic status of 40 female students (64.5\%), amounting to 0.004 exhibited significantly ( $p$ value $<0,05$ ) with $O R=5,65$. It is expected to work with officers Care Health Services Youth (PKPR) from the local health center to provide counseling on reproductive health, especially adolescents aged 12-18 years of menarche.
\end{abstract}

Keywords : Mother's age of menarche, nutritional status, socio-economic, age of menarche, junior high school students

\section{PENDAHULUAN}

Menarche adalah saat haid/menstruasi yang datang pertama kali yang terjadi pada seorang remaja putri yang sedang menginjak dewasa dan sebagai tanda bahwa wanita sudah mampu hamil (Sarwono, 2005). Usia remaja putri saat mengalami menarche bervariasi, yaitu antara usia 10-16 tahun, tetapi rata-rata pada usia 12,5 tahun. Statistik menunjukkan bahwa usia menarche dipengaruhi faktor keturunan, keadaan gizi dan kesehatan umum. Di Amerika sekitar 95\% anak perempuan mempunyai tanda pubertas pada umur 12 tahun dan umur rata-rata 12,5 tahun. Di Indonesia, gadis remaja pada waktu menarche bervariasi antara 10-16 tahun dan rata-rata menarche 12,5 tahun. Usia menarche lebih dini di daerah perkotaan dari pada yang tinggal di desa dan juga lebih lambat pada wanita yang kerja berat (Wiknjosastro, 2002). Usia menarche dapat dipengaruhi oleh kombinasi dari faktor genetik, fisik, emosional dan lingkungan. Usia menarche anak cenderung mirip dengan usia menarche ibunya ( Papalia dkk, 2008). 
Masalah yang sering terjadi pada remaja adalah ketidakseimbangan antara asupan kebutuhan atau kecukupan yang akan menimbulkan masalah gizi, baik itu berupa gizi lebih atau gizi kurang. Masalah gizi pada remaja akan berdampak penurunan fungsi reproduksi dan resiko melahirkan bayi dengan BBLR (Waryono, 2010). Usia menarche dapat dikatakan berhubungan dengan status sosial ekonomi. Pendapatan di dalam suatu keluarga acapkali dihubungkan dengan bagaimana kemampuan keluarga dalam hal pemenuhan kebutuhan gizi dimana hal pemenuhan gizi tersebut akan berkaitan pula dengan pematangan seksual pada remaja. Oleh karena itu biasanya keluarga yang mempunyai pendapatan lebih dari cukup akan secara otomatis mempengaruhi keadaan status gizinya apalagi untuk anak perempuan yang berkorelasi terhadap cepatnya menarche. (Putri, 2009).

Dengan terjadinya penurunan usia menarche akan mengakibatkan meningkatnya aktifitas seksual pada usia dini, dan mempunyai resiko tinggi terjadinya pelecehan seksual, serta terjadinya kehamilan pada usia remaja lebih besar (Sarwono, 2010). Menurut SDKI 2002-2003 10\% remaja usia remaja 15-19 tahun sudah menjadi ibu. Angka tertinggi di Provinsi Kalimantan Tengah 19\%, Jambi 18\%, Gorontalo 16\%, Sumatera Utara 4\% dan Jakarta 5\% (BKKBN, 2005). Penelitian Susdaiti (2011) di SMA negeri 5 Duri Kecamatan Mandau mengatakan usia menarche ibu menunjukkan berhubungan dengan usia menarche siswi. Usia menarche yang semakin cepat mempunyai resiko terjadinya kehamilan pada usia muda menjadi lebih besar. Pada sebagian remaja putri menarche yang cepat dapat menimbulkan keresahan, karena secara mental mereka belum siap. Sebaliknya, keterlambatan pubertas pada remaja dapat mengakibatkan keterlambatan pertumbuhan. Pertumbuhan yang lambat pada perempuan akan menyebabkan panggul sempit dan resiko untuk melahirkan bayi berat lahir rendah dikemudian hari (Soetjiningsih, 2004).

Dari survey awal yang peneliti lakukan pada minggu kedua Maret 2012 di SMP PGRI Pekanbaru, didapat jumlah siswa/i kelas VII dan VIII sebanyak 364 orang. Dari 10 siswi yang telah mengalami menstruasi, terdapat $30 \%$ siswi yang haid pada usia 11 tahun, 50\% siswi yang haid pada usia 12 tahun dan $20 \%$ siswi yang haid pada usia 13 tahun. Berdasarkan hasil wawancara, di SMP PGRI Pekanbaru belum pernah diadakan sosialisasi atau penelitian tentang kesehatan reproduksi khususnya menarche baik dari guru maupun dari petugas kesehatan, sehingga penulis tertarik untuk mengadakan penelitian mengenai faktorfaktor yang berhubungan dengan usia menarche di SMP PGRI Pekanbaru tahun 2012. Penelitian ini bertujuan untuk mengetahui faktor-faktor yang berhubungan dengan usia menarche siswi SMP PGRI Pekanbaru tahun 2012.

\section{METODE}

Jenis penelitian yang digunakan adalah analitik kuantitatif, yang dilaksanakan pada bulan Maret-April 2012 dengan desain penelitian cross sectional. Populasi dalam penelitian ini adalah seluruh siswi kelas VII dan VIII di SMP PGRI Pekanbaru yang berjumlah 167 orang sedangkan subjek penelitian ini adalah siswi SMP PGRI Pekanbaru yang duduk di kelas VII dan VIII, dan tehnik pengambilan sampel dengan menggunakan acak sederhana simple random sampling yang berjumlah 62 responden dimana pengambilan sampel ini didapatkan dengan menggunakan rumus slovin yang dikutip dalam buku Notoatmodjo (2005). Adapun variabel independen dalam penelitian ini adalah usia menarche ibu, status gizi, status sosial ekonomi dan variabel dependent adalah usia menarche siswi SMP. Jenis data yang dikumpulkan adalah data primer dengan memberikan kuesioner pada responden. Analisis bivariat dilakukan dengan uji Chi Square dengan tingkat kemaknaan $(\alpha)$ : $5 \%$.

\section{HASIL}

Hasil uji univariat diperoleh bahwa sebanyak 43 (69,4\%) siswi mengalami menarche pada usia normal, sebanyak $49(79,0 \%)$ ibu siswi mengalami menarche pada usia normal dan sebanyak $48(77,4 \%)$ siswi berstatus gizi baik, dan sebanyak $40(64,5 \%)$ siswi berstatus sosial ekonomi tinggi

Dari uji Chi Square terhadap tiga variabel, diperoleh semua variabel berhubungan dengan usia menarche yaitu ada hubungan yang signifikan antara usia menarche ibu dengan usia menarche siswi dengan nilai $\mathrm{OR}=5,52(95 \% \mathrm{CI}: 1,50-20,35)$ yang artinya siswi yang ibunya mengalami menarche pada usia tidak normal berisiko 6 kali mengalami menarche pada usia tidak normal dibandingkan siswi yang ibunya mengalami menarche pada normal, ada hubungan yang signifikan antara status gizi dengan usia menarche siswi dengan nilai $\mathrm{OR}=4,48(95 \% \mathrm{CI}$ : $1,27-5,72)$, artinya siswi dengan status gizi yang tidak baik berisiko 4 kali mengalami menarche pada usia yang tidak normal dibandingkan siswi dengan status gizi baik, ada hubungan yang signifikan antara status sosial ekonomi dengan usia menarche siswi dengan nilai $\mathrm{OR}=5,65(95 \% \mathrm{CI}: 1,75-18,23)$, artinya siswi dengan status sosial ekonomi rendah berisiko 6 kali mengalami menarche pada usia tidak normal dibandingkan siswi dengan status sosial ekonomi tinggi (tabel 1). 
Tabel. 1

Faktor- faktor yang Berhubungan dengan Menarche

\begin{tabular}{|c|c|c|c|c|c|c|c|c|c|}
\hline \multirow{3}{*}{ No } & \multirow{3}{*}{ Variabel } & \multicolumn{4}{|c|}{ Usia Menarche } & \multicolumn{2}{|c|}{ Total } & \multirow{3}{*}{$\begin{array}{c}\text { OR } \\
(95 \% \mathrm{CI})\end{array}$} & \multirow{3}{*}{$\begin{array}{c}P \\
\text { Value }\end{array}$} \\
\hline & & \multicolumn{2}{|c|}{ Normal } & \multicolumn{2}{|c|}{ Tidak Normal } & \multirow{2}{*}{$\mathbf{n}$} & \multirow{2}{*}{$\%$} & & \\
\hline & & $\mathbf{n}$ & $\%$ & $\mathbf{N}$ & $\%$ & & & & \\
\hline \multirow{3}{*}{1.} & Usia Menarche Ibu & & & & & & & \multirow{3}{*}{$\begin{array}{l}5,52 \\
(1,50-20,35)\end{array}$} & \multirow{3}{*}{0,015} \\
\hline & Normal (usia 10,5-15,5 th) & 38 & 77,6 & 11 & 22,4 & 49 & 100 & & \\
\hline & $\begin{array}{l}\text { Tidak Normal (Cepat }<10,5 \\
\text { th ,lambat, usia }>15,5 \text { th) }\end{array}$ & 5 & 38,5 & 8 & 61,5 & 13 & 100 & & \\
\hline \multirow[t]{3}{*}{2.} & Status Gizi & & & & & & & \multirow{3}{*}{$\begin{array}{l}4,48 \\
(1,27-15,72)\end{array}$} & \multirow{3}{*}{0,022} \\
\hline & Baik (IMT 18,5-25,0 kg/m² & 37 & 77,1 & 11 & 22,9 & 48 & 100 & & \\
\hline & $\begin{array}{l}\text { Tidak Baik (Kurus, jika } \\
<17,0-18,5 \mathrm{~kg} / \mathrm{m}^{2}, \text { gemuk, } \\
\text { jika IMT }>25,0-27,0 \mathrm{~kg} / \mathrm{m}^{2}\end{array}$ & 6 & 42,9 & 8 & 57,1 & 14 & 100 & & \\
\hline \multirow[t]{3}{*}{3.} & Status Sosial Ekonomi & & & & & & & \multirow{3}{*}{$\begin{array}{l}5,65 \\
(1,75-18,23)\end{array}$} & \multirow{3}{*}{0,006} \\
\hline & $\begin{array}{l}\text { Tinggi (mean penghasilan > } \\
\text { Rp.296.379,- perkapita) }\end{array}$ & 33 & 82,5 & 7 & 17,5 & 40 & 100 & & \\
\hline & $\begin{array}{l}\text { Rendah jika mean } \\
\text { penghasilan perbulan } \leq \text { Rp. } \\
\text { 296.379,- } \text { perkapita }\end{array}$ & 10 & 45,5 & 12 & 54,5 & 22 & 100 & & \\
\hline
\end{tabular}

\section{PEMBAHASAN}

\section{Hubungan Usia Menarche Ibu dengan Usia Menarche Siswi}

Hasil uji chi square menunjukkan bahwa ada hubungan yang signikan usia menarche ibu dengan usia menarche dengan $\mathrm{OR}=5,52(95 \% \mathrm{CI}: 1,50$ 20,35). Hasil penelitian ini sejalan dengan penelitian yang dilakukan Harni (2010) terhadap siswi SMP di Pekanbaru, hasil penelitian tersebut menemukan adanya hubungan yang bermakna antara usia menarche ibu dengan usia menarche siswi. Faktor genetik merupakan modal dasar mencapai hasil proses pertumbuhan. Faktor genetik antara lain termasuk faktor bawaan yang normal dan patologis, jenis kelamin, obstetrik dan ras atau suku bangsa. Apabila faktor genetik dapat berinteraksi dalam lingkungan yang baik dan optimal maka akan menghasilkan pertumbuhan yang optimal pula (Supariasa, 2002). Usia menarche dapat dipengaruhi oleh kombinasi dari faktor genetik, fisik, emosional dan lingkungan. Usia menarche anak cenderung mirip dengan usia menarche ibunya (Papalia, 2008).

Setiap manusia akan mewariskan suatu karakteristik dari generasi ke generasi. Masing-masing anak akan memiliki kode genetik yang didapat dari orang tua nya. Hal ini tidak menutup kemungkinan apabila ibu mengalami menarche pada usia normal, maka anaknya akan mengalami menarche pada usia yang normal. Sebaliknya, apabila ibu mengalami menarche lebih cepat/lambat, maka kemungkinan besar anaknya akan mendapatkan menarche lebih cepat/lambat juga.

\section{Hubungan Status Gizi dengan Usia Menarche Siswi}

Berdasarkan hasil penelitian didapat hasil bahwa status gizi berhubungan dengan usia menarche, ini terbukti dari penelitian yaitu siswi dengan status gizi tidak baik lebih beresiko 4 kali mengalami menarche pada usia tidak normal dibandingkan dengan siswi yang berstatus gizi baik.

Hasil penelitian ini juga sejalan dengan penelitian Susdaiti (2011) terhadap siswi SMA Negeri 5 Duri Kecamatan Mandau, hasil penelitian tersebut menemukan adanya hubungan yang bermakna antara status gizi dengan usia menarche siswi. Nutrisi sangat mempengaruhi kematangan seksual, remaja putri yang mendapatkan menarche lebih dini cenderung lebih berat dan lebih tinggi dibandingkan dengan remaja putri lain yang belum menarche walaupun usia nya sama. Menurut Depkes RI dalam Waryono (2010) pada remaja banyak hal yang dapat mempengaruhi menarche antara lain perubahan hormon yang dapat mempengaruhi kematangan sel dan asupan gizi yang dikonsumsi saat datangnya menarche. Suatu hal yang dapat mempengaruhi pembentukan hormon adalah asupan gizi, dengan asupan gizi yang baik dapat mempercepat pembentukan hormon-hormon yang mempengaruhi datangnya menarche.

Makanan yang dikonsumsi siswi ini berpengaruh pada pertumbuhannya, juga berpengaruh pada tingkat kesuburan siswi tersebut yang mendapatkan menarche pada usia normal. Nutrisi sangat mempengaruhi kematangan seksual, remaja putri yang mendapatkan menarche lebih dini cenderung lebih berat dan lebih tinggi dibandingkan dengan remaja putri lain yang belum menarche walaupun usia nya sama. Sebaliknya pada remaja putri yang terlambat beratnya lebih ringan walaupun tinggi 
badan sama. Makanan yang dikonsumsi siswi ini berpengaruh pada pertumbuhannya, juga berpengaruh pada tingkat kesuburan siswi tersebut yang mendapatkan menarche pada usia normal.

\section{Hubungan Status Sosial Ekonomi dengan Usia Menarche Siswi}

Berdasarkan hasil penelitian diperoleh hasil bahwa status sosial ekonomi berhubungan dengan usia menarche, dengan nilai $\mathrm{OR}=5,65(95 \% \mathrm{CI}: 1,75$ 18,23). Hasil penelitian ini sejalan dengan penelitian Sartika (2011) terhadap siswi kelas VII dan VIII SMPN 1 Bangkinang tahun 2011, hasil penelitian tersebut menemukan adanya hubungan yang bermakna antara status sosial ekonomi dengan usia menarche siswi. Menurut Hidayat (2009) status sosial ekonomi dapat mempengaruhi tumbuh kembang anak. Anak yang lahir dan dibesarkan dalam lingkungan status sosial ekonomi tinggi cenderung lebih dapat tercukupi kebutuhan gizinya dibandingkan dengan anak yang lahir dan dibesarkan dalam lingkungan sosial ekonomi yang rendah.

Usia menarche dapat dikatakan berhubungan dengan status sosial ekonomi. Pendapatan didalam suatu keluarga sering dihubungkan dengan bagaimana kemampuan keluarga dalam hal pemenuhan kebutuhan gizi dimana hal pemenuhan gizi tersebut akan berkaitan dengan pematangan seksual pada remaja. Oleh karena itu, biasanya keluarga yang mempunyai pendapatan lebih dari cukup akan secara otomatis mempengaruhi keadaan status gizinya.

\section{KESIMPULAN}

Sebagian besar $(69,4 \%)$ siswi SMP PGRI Pekanbaru mengalami menarche pada usia normal. Variabel yang berhubungan dengan usia menarche siswi SMP PGRI Pekanbaru adalah usia menarche ibu $\mathrm{OR}=5,52(95 \%$ CI : 1,50-20,35), status sosial ekonomi OR $=5,65(95 \% \mathrm{CI}: 1,75-18,23)$ dan status gizi dengan nilai $\mathrm{OR}=5,65$ (95\% CI : 1,75-18,23).

\section{SARAN}

Diharapkan kepada pihak sekolah terutama SMP PGRI Pekanbaru dapat bekerja sama dengan petugas Pelayanan Kesehatan Peduli Remaja (PKPR) dari puskesmas setempat untuk memberikan penyuluhan tentang pentingnya mengatur pola makan dengan baik dan mencapai status gizi yang normal, tidak kurang dan tidak pula berlebih, sehingga siswi mempunyai pengetahuan mengenai pentingnya gizi dan pengaruhnya terhadap usia menarche.

\section{DAFTAR PUSTAKA}

BKKBN dan UNFPA, (2005). Buku Sumber untuk Advokasi Keluarga Berencana Kesehatan
Reproduksi, Gender, Pembangunan Kependudukan, Jakarta : BKKBN

Ezra, E.S, dkk (2003). Konstitusional Psikologis Remaja Putri yang telah mengalami Menarche di SLTP $01 \quad$ Ogon Ilir, (http//www.repositiry.usu.ac.id//../chapter II.pdf) diakses 25 april 2012

Ginarhayu. (2002). Analisis Faktor-Faktor yang Berhubungan dengan Usia Menarche Remaja Putri (9-15 tahun) pada Siswi SD dan SLTP di Jakarta Timur Tahun 2002, (http://www.gilib.ui.ac.id./opac.tzhemes/libri2/det ailjsp?id=71129) Di akses 24 april 2012

Harni, M. (2010). Hubungan Status Gizi, Usia Menarche Ibu, Media Cetak dan Aktifitas Olahraga dengan Usia Menarche Siswi SMP AsShofa Pekanbaru Tahun 2010. Skripsi. Program Prodi IKM STIKes Hang Tuah Pekanbaru, Pekanbaru

Heffner, L.J (2006). At a Glance Sistem Reproduksi. Jakarta : Erlangga

Hesarika, Adelia (2010). Gambaran keterpaparan pornografi dan Perilaku Seksual Siswa di SMA Al-Azhar Medan. Skripsi. Universitas Sumatera Utara

Hidayat, A. (2009). Pengantar Ilmu Keperawatan Anak I. Jakarta : Salemba Medika

Kartono, K. (2006). Psikologi Wanita : Mengenal Gadis Remaja dan Wanita Dewasa, Bandung : Mandar Maju

Khomsan, A. (2011). Garis Kemiskinan yang Baru. (http://jakarta45.wordpress.com/2009/0501/gariskemiskinan-yang-baru/) diakses 8 Mei 2012

Liewellyn, Derek (2005). Panduan Terlengkap tentang Kesehatan Kebidanan dan Kandungan. Jakarta : Delapratasa Publishing

Manuaba, I.B.G. (2009). Memahami Kesehatan Reproduksi Wanita, Jakarta : Arcan

Notoatmodjo, S. (2002). Metodelogi Penelitian Kesehatan, Jakarta : Rineka Cipta

Notoatmodjo, S (2005). Kesehatan Masyarakat Ilmu dan Seni, Jakarta : Rineka Cipta

Papalia, dkk (2008). Human development, Jakarta : Kencana Prenada Media Group

Pulungan, P.W. (2009). Gambaran Usia Menarche pada Remaja Putri di SMP Shafiyyatul Amaliyah dan SMP Nurul Hasanah Kota Medan, (http://www.pdfbe.com/03/03f43dc991a1ed09) diakses 25 april 2012

Putri, Anni Kartika (2009). Hubungan Antara Status Gizi, Status Menarche Ibu, Media Massa, 
Aktifitas Olahraga dengan Status Menarche Siswi di SMP Islam Al-Azhar Rawamangun, Jakarta Timur. Skripsi. Universitas Indonesia.

Proverawati, A. (2009). Menarche. Jakarta : Nuha Medika

Santrock, J.W. (2007). Remaja, Jakrta : Erlangga

Sarwono, S.W. (2010). Psikologi Remaja. Jakarta : PT. Raja Gravindo Persada

Sartika, A. (2011). Faktor-Faktor yang berhubungan dengan Usia Menarche Siswi pada Siswi Kelas VII dan VIII SMPN 1 Bangkinang Tahun 2011. Skripsi. Program Prodi IKM STIKes Hang Tuah Pekanbaru, Pekanbaru

Soetjiningsih, (2004). Tumbuh kembang Remaja dan Permasalahannya, Jakarta : Sanggung Seto
Susdaiti, (2011). Faktor-Faktor yang berhubungan dengan Usia Menarche Siswi SMA Negeri 5 Duri Kecamatan Mandau Tahun 2011. Skripsi. Program Prodi IKM STIKes Hang Tuah Pekanbaru, Pekanbaru

Supriasa, (2002). Penilaian Status Gizi, Jakarta : EGC Waryono, (2010). Gizi Reproduksi, Jakarta : Pustaka Rihama

Surkesda DIY. (2008). Faktor Resiko Penyakit Tidak Menular.

(http://.dinkes.jogjaprov.go.id/../65.html) diakses 24 April 2012

Waryono, (2010). Gizi Reproduksi, Jakarta : Pustaka Rihama

Wiknjosastro, Hanifa, dkk. (2002). Ilmu kebidanan. Jakarta : Yayasan Bina Pustaka Sarwono Prawihardjo 